\title{
Respon Genotipe Padi Lokal terhadap Cekaman Rendaman di Pembibitan
}

\author{
Response of Local Rice Genotypes towards Immersion Stress in Nurseries
}

Sri Romaito Dalimunthe

Balai Pengkajian Teknologi Pertanian Sumatera Utara

\begin{tabular}{l} 
ARTICLE INFO \\
\hline Article history: \\
DOI: \\
10.30595/pspfs.v2i.169 \\
Submitted: \\
July 29, 2021 \\
Accepted: \\
Sept 10, 2021 \\
Published: \\
Nov 10, 2021 \\
\hline Keywords: \\
Immersion, Chlorophyll \\
Content, Local Variety, FR13A, \\
Tolerant, Susceptible
\end{tabular}

Tolerant, Susceptible

\begin{abstract}
Uncertain climate change impacts the difficulty of predicting the intensity of floods that hit rice fields in flood-prone areas, both the duration of the submerged plants and the height of the water surface. In order to evaluate the tolerance level and response of several local rice genotypes to submersion stress in the vegetative phase, 50 rice genotypes were screened (47 North Sumatran local varieties, 3 VUB), using special ponds to simulate flooding or inundation stress. The study used a separate plot design with three replications; the main plot was three immersion models, namely full immersion, partial soaking, and not soaking, and subplots of 50 rice genotypes. The immersion treatment was defined as a different growing environment. The results showed that in the fully submerged treatment, the recovery capacity of local rice plants only ranged from 0 $20 \%$. The new, improved varieties tested were Inpari 4 (susceptible), Inpari 3, 10, Ciherang, Inpara 2 (very susceptible), Inpari 30, FR13A (very tolerant). Submersion tolerant genotypes had a slight increase in plant height after being fully submerged. The chlorophyll content in the leaves decreased immediately after the soaking stress period (14 DAP) in all rice genotypes. The local rice genotypes tested were very susceptible to immersion; the new superior variety Inpari 4 was categorized as susceptible, while Inpari 30 and FR13A were very tolerant.
\end{abstract}

This work is licensed under a Creative Commons Attribution 4.0 International License.

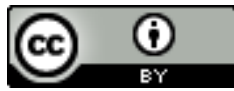

Corresponding Author:

Sri Romaito Dalimunthe

Balai Pengkajian Teknologi Pertanian Sumatera Utara

J1. AH. Nasution No. 1B Medan

Email: romaito_d@yahoo.com

\section{PENDAHULUAN}

Perubahan iklim global yang tidak menentu berdampak terhadap sulitnya memprediksi intensitas banjir yang melanda pertanaman padi di lahan rawan banjir, baik itu durasi terendamnya tanaman maupun ketinggian permukaan airnya. Biasanya, tanaman padi terendam keseluruhan bagian tanaman dan durasi cekaman terjadi sesaat (kurang dari 14 hari).

Curah hujan yang tinggi dapat menyebabkan banjir pada areal pemukiman dan persawahan sehingga merusak padi dan pada akhirnya terjadi kegagalan panen. Banjir yang mengakibatkan cekaman terhadap tanaman padi di wilayah Asia Selatan dan Tenggara diperkirakan mencapai 15 juta hektar setiap tahunnya (Septiningsih dkk., 2009). Di Indonesia potensi areal persawahan yang terkena cekaman banjir cukup luas sekitar 13,3 juta ha terdiri atas 4,2 juta ha genangan dangkal, 6,1 juta ha genangan sedang, dan 3,0 juta ha genangan dalam (Nugroho dkk., 1993). Terjadinya peningkatan curah hujan dan kenaikan permukaan air laut 
akibat pemanasan global akan mengakibatkan semakin bertambahnya luas areal persawahan yang mengalami cekaman genangan (CGIAR, 2006).

Sampai saat ini, di Indonesia, jumlah varietas yang toleran masih sangat terbatas, antara lain Inpara 3, 4 dan 5. Guna mengantisipasi kendala iklim tersebut, pemulia terdorong untuk mengembangkan padi yang toleran terhadap cekaman abiotik, seperti kekeringan, salinitas tinggi, maupun genangan atau banjir. Oleh karena itu, dalam rangka ketahanan pangan perlu dikembangkan padi yang toleran genangan (Fukao and Bailey, 2008).

Tujuan penelitian ini adalah (1) untuk mengevaluasi tingkat toleransi dan respon beberapa genotipe padi lokal terhadap cekaman rendaman pada fase vegetatif (2) mengetahui perbandingan respon tanaman padi pada lingkungan tercekam rendaman penuh, terendam sebagian dan tidak direndam (3) mengetahui mekanisme toleransi tanaman padi terhadap cekaman rendaman.

Melalui penelitian ini diharapkan dapat diperoleh genotip padi lokal yang toleran terhadap rendaman.

\section{METODE PENELITIAN}

\section{Waktu dan Tempat Penelitian}

Penelitian ini dilakukan pada bulan Agustus - Oktober 2018, bertempat di rumah plastik BPTP Sumatera Utara dengan ketinggian $\pm 25 \mathrm{mdpl}$, menggunakan bak/kolam khusus untuk mensimulasi banjir atau cekaman rendaman.

\section{Bahan dan Alat}

Materi genetik yang digunakan dalam penelitian ini adalah 50 genotipe padi lokal di Provinsi Sumatera Utara yang terdiri atas 47 varietas Badan Litbang dan lokal dan 3 varietas pembanding (Tabel 1).

Tabel 1. Genotipe Padi yang Digunakan dalam Penelitian

\begin{tabular}{|c|c|c|c|c|c|}
\hline No & Genotipe & SUMBER & No & Genotipe & SUMBER \\
\hline 1 & Inpari 3 & Badan Litbang & 26 & Si Bosur & $\begin{array}{l}\text { Desa Lumban Sui-sui Toman, } \\
\text { Samosir }\end{array}$ \\
\hline 2 & Inpari 4 & Badan Litbang & 27 & Aries & Lumban sui-sui, Dolok, samosir \\
\hline 3 & Inpari 10 & Badan Litbang & 28 & Si Kodok & $\begin{array}{l}\text { Desa Hutatinggi, Kec. } \\
\text { Pangururan, Samosir }\end{array}$ \\
\hline 4 & Inpari 30 & Badan Litbang & 29 & Si Jior & $\begin{array}{l}\text { Desa Huta Tinggi I, kec. } \\
\text { Pangururan, Samosir }\end{array}$ \\
\hline 5 & Inpara 2 & Badan Litbang & 30 & IA. Apolio & Urat Suhut Nihuta, Samosir \\
\hline 6 & Ciherang & Badan Litbang & 31 & Sigandang & Sait Nihuta, Tarutung \\
\hline 7 & FR13A & BB padi & 32 & Si Gempal & Sait Nihuta, Tarutung \\
\hline 8 & IR42 & BB padi & 33 & Si Pendek & $\begin{array}{l}\text { Desa Hutapea Banuarea, } \\
\text { Tarutung, Tapanuli Utara }\end{array}$ \\
\hline 9 & Indragiri & $\begin{array}{l}\text { Desa Stabat Lama Barat, } \\
\text { Kec. Wampu, Kab. } \\
\text { Langkat }\end{array}$ & 34 & Si Permaisuri & Desa hutapea banuarea \\
\hline 10 & Kuku Balam & Tanjung leidong, Labura & 35 & Si Pulo manggil & Sait Nihuta, Tarutung \\
\hline 11 & Kuku balam & $\begin{array}{l}\text { Desa Teluk pulai } \\
\text { Dalam, Leidong, Labura }\end{array}$ & 36 & $\begin{array}{l}\text { Si Cantik Manis } \\
\text { Pendek }\end{array}$ & Humbang Hasundutan \\
\hline 12 & $\begin{array}{l}\text { Kuku Balam } \\
\text { (2) }\end{array}$ & $\begin{array}{l}\text { Buah Dialas, Ds Blok 2, } \\
\text { Kel. Tanjung Leidong }\end{array}$ & 37 & Sicantik Manis & Humbang Hasundutan \\
\hline 13 & $\begin{array}{l}\text { Kuku Balam } \\
\text { (2) }\end{array}$ & $\begin{array}{l}\text { Desa Urat, Kec. } \\
\text { Nainggolan, Kab. } \\
\text { Samosir }\end{array}$ & 38 & Si Pandan & Humbang Hasundutan \\
\hline 14 & $\begin{array}{l}\text { Kuku Balam } \\
\text { (KKA) } 1\end{array}$ & Desa Urat, Samosir & 39 & Si Datang & Humbang Hasundutan \\
\hline 15 & $\begin{array}{l}\text { Kuku Balam } \\
\text { (KKB) B2 }\end{array}$ & Desa Urat, Samosir & 40 & Si Rumbia & Humbang Hasundutan \\
\hline 16 & $\begin{array}{l}\text { Kuku Balam } \\
(\mathrm{KKB}) \mathrm{A} 2\end{array}$ & Desa Urat, samosir & 41 & Si Tamba Tua & $\begin{array}{l}\text { Desa Pardamean, Nainggolan, } \\
\text { Pahae Jae }\end{array}$ \\
\hline 17 & Padi pulut & $\begin{array}{l}\text { Desa Stabat Lama Barat, } \\
\text { Kec. Wampu, Kab. } \\
\text { Langkat }\end{array}$ & 42 & Si 64 Narara & $\begin{array}{l}\text { Desa Negeri Nainggolan, } \\
\text { lumban Pardomuan, } \\
\text { Pahae Jae }\end{array}$ \\
\hline 18 & Ramos Tebing & $\begin{array}{l}\text { Desa Aek Siancimun, } \\
\text { Tarutung }\end{array}$ & 43 & Si Atas Barita & samosir \\
\hline 19 & Ramos kuning & Desa Aek Siancimun, & 44 & Si Ramos & Majanggut I, pakpak Bharat \\
\hline
\end{tabular}


(12)

\begin{tabular}{|c|c|}
\hline \multirow[t]{2}{*}{20} & Sikancang \\
\hline & Gomuk \\
\hline \multirow[t]{2}{*}{21} & Si Kancang \\
\hline & Gomuk (2 \\
\hline \multirow[t]{2}{*}{22} & Si Kancang \\
\hline & Gomuk (4) \\
\hline & Si Kariting \\
\hline \multirow[t]{2}{*}{24} & Si Bandun \\
\hline & Merah \\
\hline & Si Peget \\
\hline
\end{tabular}

Tanjung Maribun,

Tarutung

Desa Ari Niato, Dusun

Pardu Pasar, Samosir

Desa Ari Niate, Dusun

Pardu Pasar, Samosir

Desa Ari Niate, dusun

Pardu Pasar, Samosir

Desa Lumban Suli-suli,

Toman, Samosir

Desa Bonor Sirait,

Pandiangan, nainggolan, samosir

Desa Lumban Suhi-suhi, $50 \quad$ Siregi

$45 \quad$ Si Boru

Tombun

46 Si Angkat

Sawah

$47 \quad$ Cengkareng

$48 \quad$ Raden

49 Sirogi

Dolok, Samosir
Soit Ni huta

Desa Karing, kec. Berampu

Desa Siatas Barita

Huta Raja Sipaholon

Dusun IV, Desa Tetehosi Afia, Gunung Sitoli, Nias

Dusun IV, Desa Tetehosi Afia, Gunung Sitoli, Nias

Percobaan di rumah plastik dilakukan menggunakan metode direct seeded in trays in green house (IRRI, 2002). Perlakuan rendaman dilakukan pada fase vegetatif, yaitu 10 hari setelah semai (HSS). Percobaan ini terdiri atas tiga macam perendaman yaitu direndam penuh, direndam sebagian dan tidak direndam. Durasi cekaman rendaman di lapangan dihentikan apabila varietas pembanding peka IR42 sudah menunjukkan gejala mati (skor 9). Pada penelitian ini cekaman rendaman diberikan selama 14 hari. Durasi rendaman 14 hari diberikan dengan pertimbangan bahwa hingga saat ini durasi maksimal tanaman padi toleran rendaman adalah selama 14 hari, yaitu untuk Inpara 4 dan 5 (BB Padi, 2013). Perendaman dilakukan menggunakan bak air berukuran panjang $150 \mathrm{~cm}$, lebar $150 \mathrm{~cm}$, dan tinggi $140 \mathrm{~cm}$ untuk perendaman penuh (complete submergence), menggunakan ember berukuran besar untuk perendaman sebagian.

Pengisian air ke dalam bak dilakukan perlahan dan aliran air yang masuk tidak langsung mengenai tanaman agar tidak merusak bibit tanaman yang masih muda. Ketinggian air dipertahankan pada kisaran 110$120 \mathrm{~cm}$ agar tidak ada bagian tanaman yang muncul di atas permukaan air selama durasi rendam.

Pengamatan di rumah plastik dilakukan pada saat sebelum dan lima hari sesudah rendaman dihentikan. Tingkat toleransi tanaman padi terhadap cekaman rendaman ditentukan berdasarkan perhitungan persentase daya pulih genotipe-genotipe yang diuji dibandingkan dengan persentase daya pulih pembanding toleran, yaitu sangat toleran $(100 \%)$, toleran $(95-99 \%)$, moderat $(75-94 \%)$, peka $(50-74 \%)$ dan sangat peka $(0-49 \%)$ (IRRI, 2002).

Pada percobaan ini tanaman direndam di dalam bak plastik yang dibiarkan terbuka sehingga sirkulasi udara dapat berlangsung baik dengan suhu maksimum minimum yang stabil.

\section{Pengamatan}

Pengamatan tanaman contoh

Parameter yang diamati diambil dari lima tanaman contoh secara acak pada masing-masing nomor tanaman. Pengamatan dilakukan sebelum periode rendaman (10 HSS) dan sesaat setelah periode rendaman (14 HST) / pemulihan yang meliputi :

1. Persentase tanaman yang hidup/daya pulih tanaman setelah rendaman (\%)

2. Panjang akar $(\mathrm{cm})$, diukur dari pangkal akar sampai ujung akar terpanjang.

3. Tinggi tanaman sebelum dan sesudah direndam $(\mathrm{cm})$, pengukuran dilakukan mulai dari permukaan tanah hingga ujung malai terpanjang.

4. Jumlah daun (helai)

5. kandungan klorofil total

6. Berat Basah $(\mathrm{g})$

7. Berat Kering $(\mathrm{g})$

\section{Metode Penelitian}

Tata letak petak percobaan disusun sesuai dengan pola rancangan petak terpisah (split plot design), diulang tiga kali, dengan anak petak 100 genotipe padi dan petak utama tiga model perendaman, yaitu perendaman penuh (complete submergence), rendam sebagian dan tidak direndam. Perlakuan rendaman diartikan sebagai lingkungan tumbuh yang berbeda. 


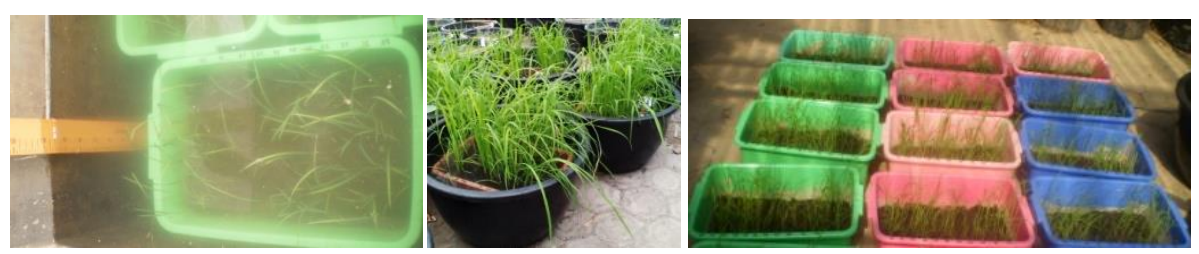

Gambar 1. Perlakuan rendaman (a) terendam penuh, (b) terendam sebagian dan (c) tidak direndam

Percobaan dilakukan mengikuti metode baku dari IRRI (Pamplona et al., 2007; Vergara, B.S., Mazarado, 1976). Sebanyak 50 galur diuji dengan varietas IR42 sebagai pembanding peka dan varietas FR 13A sebagai pembanding toleran. Benih direndam dalam air selama 24 jam kemudian dicuci dan diperam selama 24 jam. Media tanam berupa tanah liat (sawah) dalam pot plastik ukuran $40 \mathrm{~cm}$ x $25 \mathrm{~cm}$ x $14 \mathrm{~cm}$. Media dipupuk dengan 2 gram urea, 1 gram TSP serta 2 gram KCL per pot. Benih ditanam dalam barisan sebanyak 12 biji, dan benih ditutup dengan tanah 2-3 cm. Setiap pot dibagi menjadi 10 baris. Pada umur 10 hari bibit yang lemah dibuang dan disisakan 10 tanaman dan diukur tinggi tanamannya. Tanaman berikut pot direndam dalam tangki air ukuran panjang $150 \mathrm{~cm}$, lebar $150 \mathrm{~cm}$, dan tinggi $140 \mathrm{~cm}$.

Ketinggian air dipertahankan $50 \mathrm{~cm}$ di atas permukaan tanah, kondisi air bening, dan suhu air $27{ }^{\circ} \mathrm{C}$ selama 14 hari. Air kemudian dibuang dan tanaman dibiarkan untuk pulih. Skoring dilakukan 6 hari setelah pembuangan air dengan menghitung tanaman yang hidup (ditunjukkan dengan daun yang berwarna hijau). Penilaian menggunakan Standard Evaluation System for Rice (IRRI, 1996).

Persentase tanaman yang hidup = jumlah tanaman yang daunnya hijau $\times 100 \%$

Skor $1=100 \%$ (Sangat toleran)

Skor $3=95-99 \%$ (Toleran)

Skor $5=75-94 \%$ (Moderat)

Skor $7=50-74 \%$ (Rentan)

Skor $9=0-49 \%$ (Sangat rentan)

Untuk mengetahui pengaruh perendaman pada galur, data hasil pengamatan dianalisis dengan menggunakan analisis varian. Apabila terdapat perbedaan, dilanjutkan dengan menggunakan uji Beda Nyata Terkecil (BNT) dan DMRT dengan taraf nyata 5\% (Gomez and Gomez, 1995).

\section{HASIL DAN PEMBAHASAN}

Hasil analisis ragam gabungan menunjukkan bahwa terdapat perbedaan yang sangat nyata diantara genotipe, lingkungan dan interaksi antara genotipe dan lingkungan untuk semua karakter yang diamati. Hal ini menunjukkan bahwa setiap genotipe yang diuji akan memberikan respon yang berbeda terhadap lingkungan dimana pengujian dilakukan.

Tabel 2. Analisis Ragam Gabungan Antara Genotipe, dan Lingkungan terhadap Karakter Vegetatif Padi Lokal

\begin{tabular}{lcccc}
\hline \multirow{2}{*}{ Karakter } & \multicolumn{3}{c}{ Sumber Keragaman } & KK $(\%)$ \\
\cline { 2 - 4 } & Genotipe & Lingkungan & Interaksi \\
\hline Tinggi tan sebelum direndam & $* *$ & $* *$ & $* *$ & 3,41 \\
Tinggi tan setelah direndam & $* *$ & $* *$ & $* *$ & 1,34 \\
Jumlah klorofil total & $* *$ & $* *$ & $* *$ & 1,75 \\
Jumlah daun & $* *$ & $* *$ & $* *$ & 12,79 \\
Panjang akar & $* *$ & $* *$ & $* *$ & 6,20 \\
Bobot basah per tanaman & $* *$ & $* *$ & $* *$ & 12,15 \\
Bobot kering per tanaman & $* *$ & $* *$ & $* *$ & 17,16 \\
Pertambahan tinggi tanaman & $* *$ & $* *$ & $* *$ & 3,06 \\
\hline
\end{tabular}

Ket $:$ tn $=$ tidak nyata, $*$ nyata pada taraf $5 \%, * *=$ nyata pada taraf $1 \%$.

Berdasarkan hasil analisis ragam gabungan tersebut diketahui bahwa perbedaan karakteristik fenotipe pada karakter yang diamati sangat dipengaruhi oleh interaksi genotipe dan lingkungannya. Pengaruh interaksi genotipe dan lingkungan yang nyata menggambarkan terdapat perbedaan respon genotipe pada lingkungan yang beragam.

Pada penelitian ini, koefisien keragaman (KK) dari karakter-karakter yang diuji nilainya bervariasi dari terendah $(1,34 \%)$ pada karakter tinggi tanaman setelah direndam sampai tertinggi $(17,16 \%)$ pada bobot kering per tanaman. Nilai koefisien keragaman menunjukkan tingkat ketepatan dengan perlakuan yang 
diperbandingkan. Semakin tinggi nilai KK, semakin rendah keandalan suatu percobaan. Nilai KK beragam tergantung pada jenis percobaan, tanaman dan sifat yang diukur (Gomez and Gomez, 1995). Nilai KK dari parameter pertumbuhan dan komponen hasil dikatakan rendah apabila tidak lebih dari $20 \%$ pada percobaan lapangan.

\section{Respon Genotipe Padi terhadap Perendaman pada Fase Vegetatif}

Berdasarkan standard evaluation system (IRRI, 2002), skoring toleransi terhadap cekaman rendaman dilakukan lima hari sesudah cekaman rendaman dihentikan. Hal ini disebabkan sesaat sesudah cekaman rendaman dihentikan hampir semua genotipe menunjukkan gejala layu sehingga sulit apabila langsung dilakukan skoring dan pengamatan tinggi tanaman.

\section{Daya pulih tanaman}

Indikator genotipe padi toleran rendaman dapat dievaluasi secara langsung berdasarkan persentase daya pulih tanaman (recovery) setelah rendaman. Hasil pengamatan terhadap persentase daya pulih tanaman di rumah plastik menunjukkan bahwa semua genotipe padi lokal sangat rentan terhadap rendaman. dimana pada perlakuan terendam penuh, daya pulih tanaman hanya berkisar 0-20\%. Sementara padi varietas unggul baru yang diuji, hanya Inpari 4 yang termasuk kategori rentan, sedangkan Inpari 3, 10, Ciherang dan Inpara 2 masih dalam kategori sangat rentan. Kecuali Inpari 30 yang tergolong sangat toleran.

Tabel 2. Rata-rata persentase daya pulih tanaman (DPT) padi sesudah cekaman rendaman pada tiga perlakuan di rumah kaca pada lingkungan tercekam rendaman.

\begin{tabular}{|c|c|c|c|c|c|c|c|c|}
\hline \multirow[t]{2}{*}{ No } & \multirow[t]{2}{*}{ Genotip } & \multicolumn{2}{|c|}{$\begin{array}{l}\text { Terendam } \\
\text { penuh }\end{array}$} & \multicolumn{2}{|c|}{$\begin{array}{l}\text { Terendam } \\
\text { sebagian }\end{array}$} & \multicolumn{2}{|c|}{ Tidak direndam } & \multirow[t]{2}{*}{$\mathrm{BK}$} \\
\hline & & DPT & Skor & DPT & Skor & DPT & Skor & \\
\hline 1 & Inpari 3 & 0 & 9 & 100 & 1 & 100 & 1 & 0.14 \\
\hline 2 & Inpari 4 & 60 & 7 & 100 & 1 & 100 & 1 & 0.17 \\
\hline 3 & Inpari 10 & 40 & 9 & 100 & 1 & 100 & 1 & 0.23 \\
\hline 4 & Inpari 30 & 100 & 1 & 100 & 1 & 100 & 1 & 0.18 \\
\hline 5 & Inpara 2 & 0 & 9 & 100 & 1 & 100 & 1 & 0.45 \\
\hline 6 & Ciherang & 10 & 9 & 100 & 1 & 100 & 1 & 0.26 \\
\hline 7 & FR13A & 100 & 1 & 100 & 1 & 100 & 1 & 0.20 \\
\hline 8 & IR42 & 0 & 9 & 100 & 1 & 100 & 1 & 0.17 \\
\hline 9 & Indragiri & 0 & 9 & 100 & 1 & 100 & 1 & 0.22 \\
\hline 10 & Kuku Balam & 0 & 9 & 100 & 1 & 100 & 1 & 0.17 \\
\hline 11 & Kuku balam & 0 & 9 & 100 & 1 & 100 & 1 & 0.11 \\
\hline 12 & Kuku Balam (2) & 0 & 9 & 100 & 1 & 100 & 1 & 0.14 \\
\hline 13 & Kuku Balam (2) & 0 & 9 & 100 & 1 & 100 & 1 & 0.19 \\
\hline 14 & Kuku Balam (KKA) 1 & 0 & 9 & 100 & 1 & 100 & 1 & 0.15 \\
\hline 15 & Kuku Balam (KKB) B2 & 0 & 9 & 100 & 1 & 100 & 1 & 0.16 \\
\hline 16 & Kuku Balam (KKB) A2 & 0 & 9 & 100 & 1 & 100 & 1 & 0.17 \\
\hline 17 & Padi pulut & 10 & 9 & 100 & 1 & 100 & 1 & 0.25 \\
\hline 18 & Ramos Tebing & 10 & 9 & 100 & 1 & 100 & 1 & 0.12 \\
\hline 19 & Ramos kuning (12) & 0 & 9 & 100 & 1 & 100 & 1 & 0.22 \\
\hline 20 & Sikancang Gomuk & 10 & 9 & 100 & 1 & 100 & 1 & 0.18 \\
\hline 21 & Si Kancang Gomuk (2) & 20 & 9 & 100 & 1 & 100 & 1 & 0.20 \\
\hline 22 & Si Kancang Gomuk (4) & 0 & 9 & 100 & 1 & 100 & 1 & 0.20 \\
\hline 23 & Si Kariting & 0 & 9 & 100 & 1 & 100 & 1 & 0.11 \\
\hline 24 & Si Bandung Merah & 0 & 9 & 100 & 1 & 100 & 1 & 0.23 \\
\hline 25 & Si Peget & 0 & 9 & 100 & 1 & 100 & 1 & 0.14 \\
\hline 26 & Si Bosur & 0 & 9 & 100 & 1 & 100 & 1 & 0.10 \\
\hline 27 & Aries & 0 & 9 & 100 & 1 & 100 & 1 & 0.07 \\
\hline 28 & Si Kodok & 0 & 9 & 100 & 1 & 100 & 1 & 0.21 \\
\hline 29 & Si Jior & 0 & 9 & 100 & 1 & 100 & 1 & 0.18 \\
\hline 30 & IA. Apolio & 0 & 9 & 100 & 1 & 100 & 1 & 0.10 \\
\hline 31 & Sigandang & 0 & 9 & 100 & 1 & 100 & 1 & 0.10 \\
\hline 32 & Si Gempal & 10 & 9 & 100 & 1 & 100 & 1 & 0.16 \\
\hline 33 & Si Pendek & 0 & 9 & 100 & 1 & 100 & 1 & 0.17 \\
\hline 34 & Si Permaisuri & 0 & 9 & 100 & 1 & 100 & 1 & 0.12 \\
\hline 35 & Si Pulo manggil & 0 & 9 & 100 & 1 & 100 & 1 & 0.14 \\
\hline
\end{tabular}




\begin{tabular}{|c|c|c|c|c|c|c|c|c|}
\hline 36 & Si Cantik Manis Pendek & 0 & 9 & 100 & 1 & 100 & 1 & 0.15 \\
\hline 37 & Sicantik Manis & 0 & 9 & 100 & 1 & 100 & 1 & 0.14 \\
\hline 38 & Si Pandan & 0 & 9 & 100 & 1 & 100 & 1 & 0.20 \\
\hline 39 & Si Datang & 0 & 9 & 100 & 1 & 100 & 1 & 0.05 \\
\hline 40 & Si Rumbia & 0 & 9 & 100 & 1 & 100 & 1 & 0.23 \\
\hline 41 & Si Tamba Tua & 0 & 9 & 100 & 1 & 100 & 1 & 0.15 \\
\hline 42 & Si 64 Narara & 0 & 9 & 100 & 1 & 100 & 1 & 0.14 \\
\hline 43 & Si Atas Barita & 0 & 9 & 100 & 1 & 100 & 1 & 0.15 \\
\hline 44 & Si Ramos & 0 & 9 & 100 & 1 & 100 & 1 & 0.10 \\
\hline 45 & Si Boru Tombun & 0 & 9 & 100 & 1 & 100 & 1 & 0.16 \\
\hline 46 & Si Angkat Sawah & 0 & 9 & 100 & 1 & 100 & 1 & 0.28 \\
\hline 47 & Cengkareng & 0 & 9 & 100 & 1 & 100 & 1 & 0.14 \\
\hline 48 & Raden & 0 & 9 & 100 & 1 & 100 & 1 & 0.26 \\
\hline 49 & Sirogi & 10 & 9 & 100 & 1 & 100 & 1 & 0.20 \\
\hline 50 & Siregi & 10 & 9 & 100 & 1 & 100 & 1 & 0.13 \\
\hline
\end{tabular}

Keterangan : DPT = Daya Pulih Tanaman; LTR = Lingkungan Tercekam Rendaman; $r$ DPT = koefisien korelasi terhadap daya pulih tanaman; rHasil = koefisien korelasi terhadap berat kering; $* *=$ nyata pada taraf $\alpha$ $1 \%$;

Dari 50 genotipe padi yang diuji pada perendaman penuh, hampir semua genotipe menunjukkan gejala layu bahkan mati. Hanya ada 2 varietas yang tergolong sangat toleran, yakni Inpari 30 dan FR13A. kedua varietas tersebut merupakan varietas yang mengandung gen pengendali toleransi cekaman rendaman.

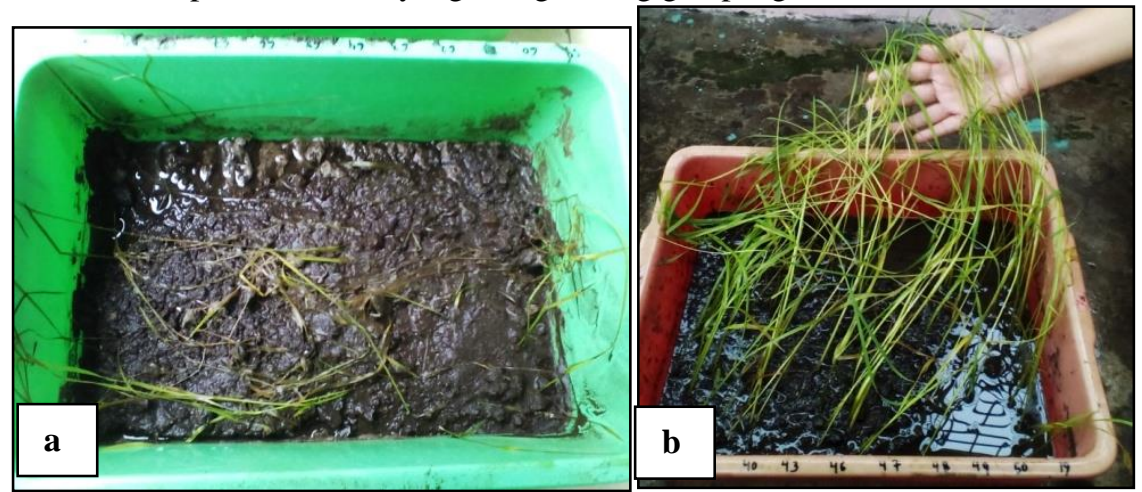

Gambar 2. Kondisi padi sesaat setelah keluar dari cekaman (a) rendaman penuh dan (b) terendam sebagian

Faktor utama penyebab kerusakan tanaman akibat cekaman rendaman adalah (1) terganggunya pertukaran gas $\mathrm{CO} 2$ dan $\mathrm{O} 2$ antara tanaman dan lingkungannya, (2) berkurangnya penetrasi cahaya matahari dan (3) adanya gen pengendali toleransi terhadap cekaman rendaman. Ketiga faktor tersebut menyebabkan terhambatnya proses respirasi dan fotosintesis tanaman selama tercekam rendaman. Semua respon fisiologis dalam mengatasi cekaman rendaman diatur oleh gen Subl atau lebih spesifik lagi gen SublA, merupakan tipe gen ethylene-response factor like genes (Xu et al., 2006). Adanya gen tersebut mengurangi sensitivitas tanaman padi terhadap etilen, yaitu hormon tanaman yang mendorong proses pemanjangan tanaman, pelepasan energi yang disimpan dan penguraian klorofil.

Sampai saat ini hanya ada satu varietas yang sangat toleran (skor 1) terhadap cekaman rendaman, yaitu varietas FR13A. Varietas ini memiliki toleransi yang tinggi terhadap rendaman lebih dari 14 hari. FR13A merespon terhadap cekaman rendaman dengan tidak mengalami pemanjangan. Pemanjangan batang merupakan respon morfologi paling umum pada tanaman yang tercekam rendaman air (Harada et al., 2005; Ookawara et al., 2005), namun toleransi tanaman padi terhadap rendaman berkorelasi negatif dengan kemampuan pemanjangan batang. Mekanisme toleransi tanaman padi terhadap cekaman rendaman keseluruhan dengan memperlambat laju pertumbuhan tanaman selama rendaman diperkuat juga dengan hasil analisis korelasi yang negatif nyata antara persentase daya pulih tanaman dengan pertambahan tinggi tanaman (Yullianida dkk., 2014).

\section{Tinggi tanaman $(\mathbf{c m})$}

Genotipe yang toleran rendaman, yaitu Inpari 30 (G4) dan FR13A (G7) memiliki pertambahan tinggi tanaman yang kecil sesudah terendam penuh, yaitu masing-masing sebesar 3,04 dan 9,3. Hal ini sesuai dengan hasil penelitian Ikhwani et al. (2010) yang menunjukkan bahwa genotipe IR64 Sub1 yang toleran rendaman 
mengalami stagnasi pertumbuhan selama perendaman, diindikasikan dengan rendahnya pertambahan tinggi tanaman dan laju pemanjangan batang yang lambat.

Fukao dan Bailey-Serres (2008) melaporkan bahwa cekaman rendaman menyebabkan kandungan etilen dan asam giberelat (GA) meningkat sehingga memacu pertambahan tinggi tanaman. Gen Sub-1 mempunyai peran menghambat kerja hormon etilen dan GA tersebut, sehingga laju pemanjangan batang varietas yang memiliki gen $S u b-1$ lebih lambat dibandingkan varietas yang tidak memiliki gen $S u b-1$ dalam kondisi cekaman rendaman. Menurut Setter et al. (1987), cekaman rendaman menyebabkan meningkatnya produksi hormon etilen dan GA pada tanaman. Selanjutnya menurut Perata dan Voesenek (2006), Fukao dan Bailey-Serres (2008), cekaman rendaman mengakibatkan akumulasi etilen yang kemudian menginduksi transkripsi gen SublA sehingga terjadi akumulasi protein SublA. Selanjutnya SublA menghambat ekspansi A (ExpA) dan sukrosa sintase (Sus 3) sehingga menghambat pertumbuhan.
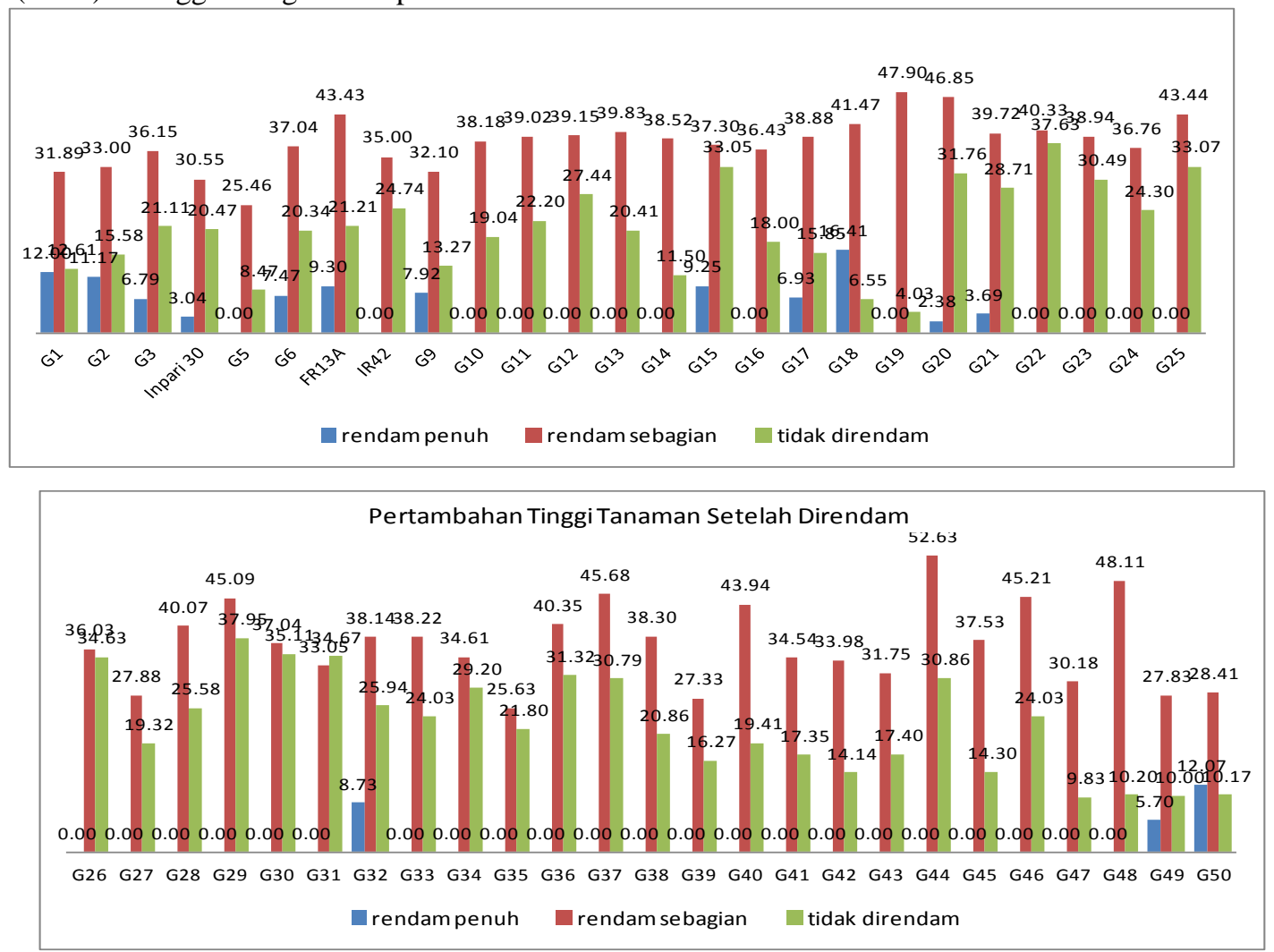

Gambar 3. Pertambahan tinggi tanaman padi $(\mathrm{cm})$ sesudah cekaman rendaman pada ketiga sub-percobaan di rumah plastik

Pertambahan tinggi tanaman atau pemanjangan batang tidak diinginkan pada kondisi cekaman rendaman keseluruhan karena dapat mengakibatkan diremobilisasinya karbohidrat yang tersimpan (Nugraha dkk., 2011). Ketika air surut, tanaman yang menggunakan cadangan energi untuk pemanjangan batang sudah tidak memiliki energi yang cukup untuk melakukan pemulihan.

\section{Jumlah daun (helai)}

Jumlah daun tanaman padi setelah pemulihan terlihat berbeda, dimana pada kondisi yang terndam penuh, daun yang tetap bertahan sebanyak rata-rata 3 helai daun, ada beberapa tanaman padi yang tidak mampu mempertahankan daunnya, sedangkan pada genotipe padi yang sangat rentan daun dan batangnya membusuk dan mati. 

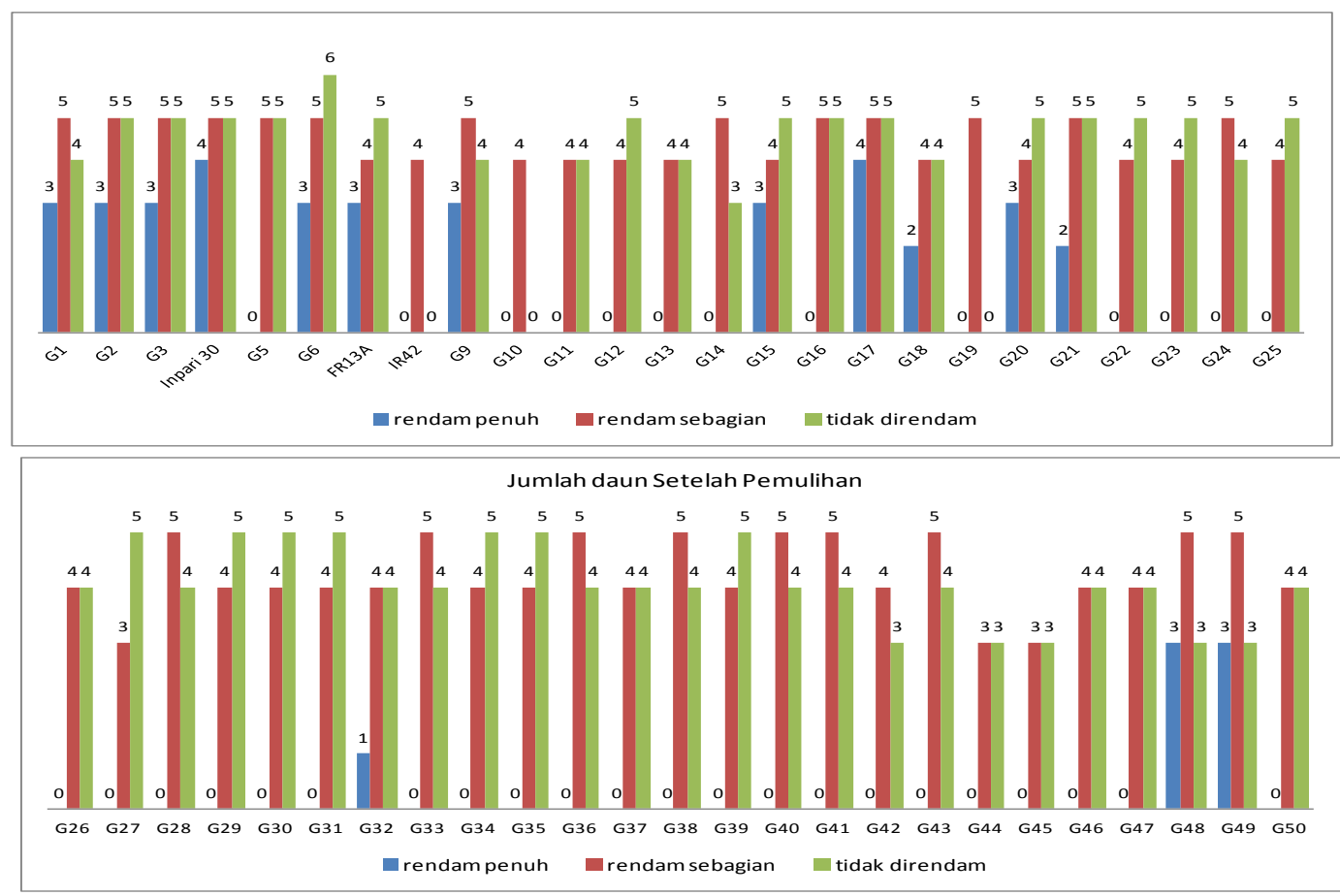

Gambar 4. Jumlah daun (helai) tanaman padi sesudah cekaman rendaman pada ketiga sub-percobaan di rumah plastik

\section{Jumlah Klorofil total daun}

Kandungan klorofil pada daun mengalami penurunan sesaat setelah periode cekaman rendaman (14 HST) pada semua genotipe padi. Hal ini disebabkan tanaman dalam kondisi terendam mengalami peningkatan kandungan etilen yang berdampak pada penurunan kandungan klorofil pada tanaman. Menurut Setter et al. (1987), cekaman rendaman menyebabkan meningkatnya produksi hormon etilen dan asam giberelat pada tanaman. Ella et al. (2003) melaporkan bahwa hormon etilen menyebabkan degradasi klorofil sehingga daun cepat senesen.

Menurut Ikhwani et al. (2010), tanaman yang terendam fotosintesisnya sangat terhambat, sehingga untuk pertumbuhan organ yang sedang tumbuh diperlukan perombakan jaringan lain yang mengandung $\mathrm{N}$ (remobilisasi N), termasuk klorofil sehingga daun menjadi pucat atau kuning. Selain itu fotosintesis yang terhambat pada tanaman yang terendam disebabkan oleh cahaya yang diterima tanaman tersebut rendah.
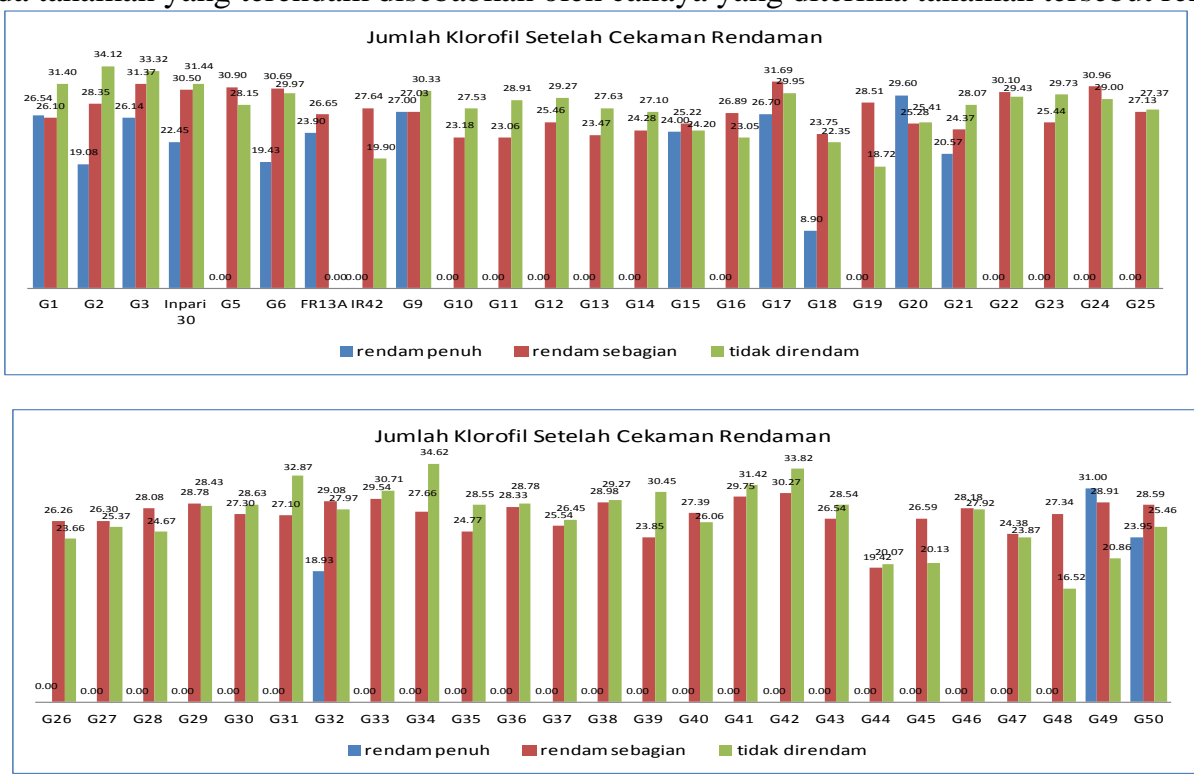

Gambar 5. Jumlah klorofil total tanaman padi sesudah cekaman rendaman pada ketiga sub-percobaan di rumah plastik 


\section{Panjang Akar (cm)}
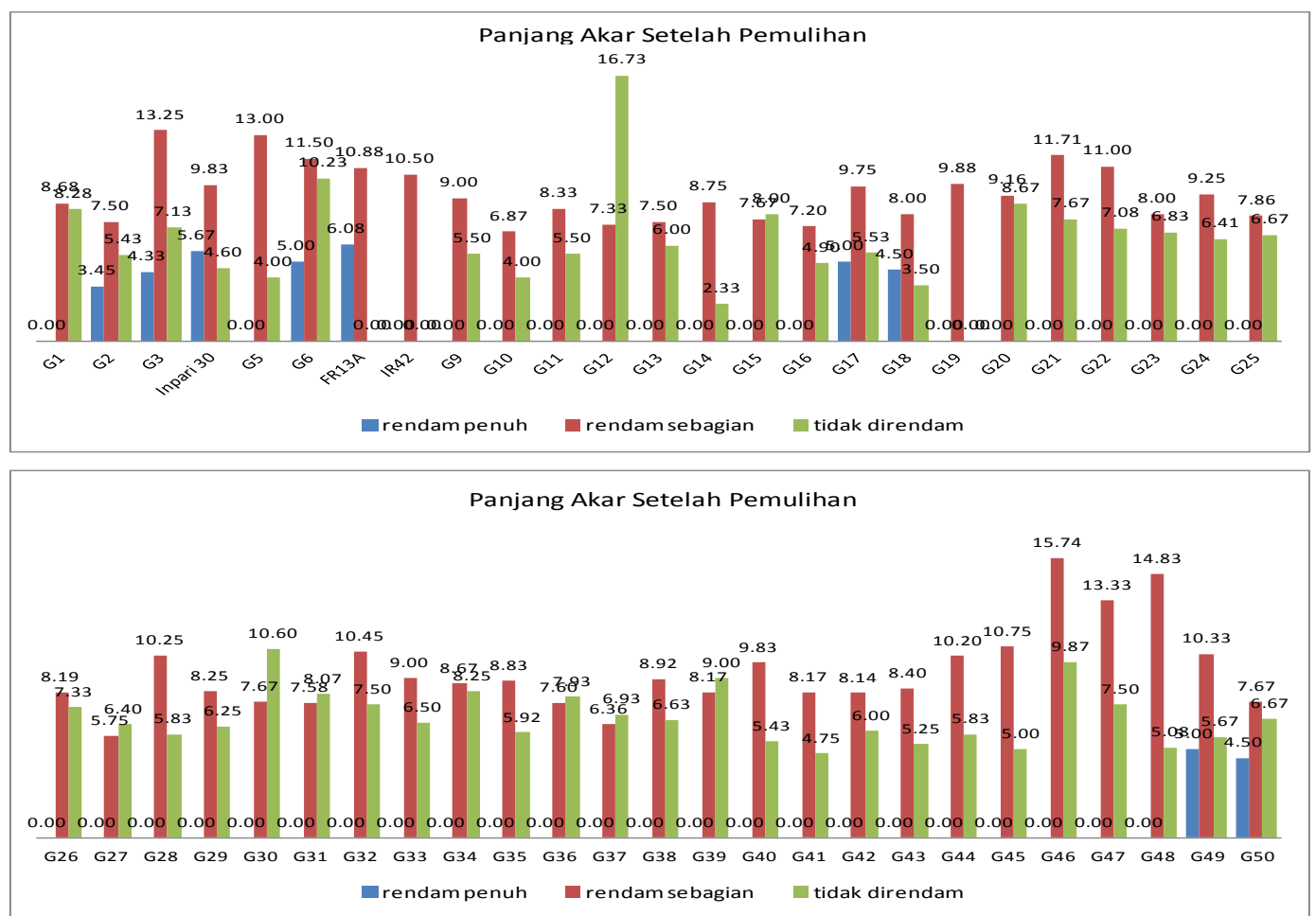

Gambar 6. Panjang akar $(\mathrm{cm})$ tanaman padi sesudah cekaman rendaman pada ketiga sub-percobaan di rumah plastik

\section{Berat basah per tanaman (g)}
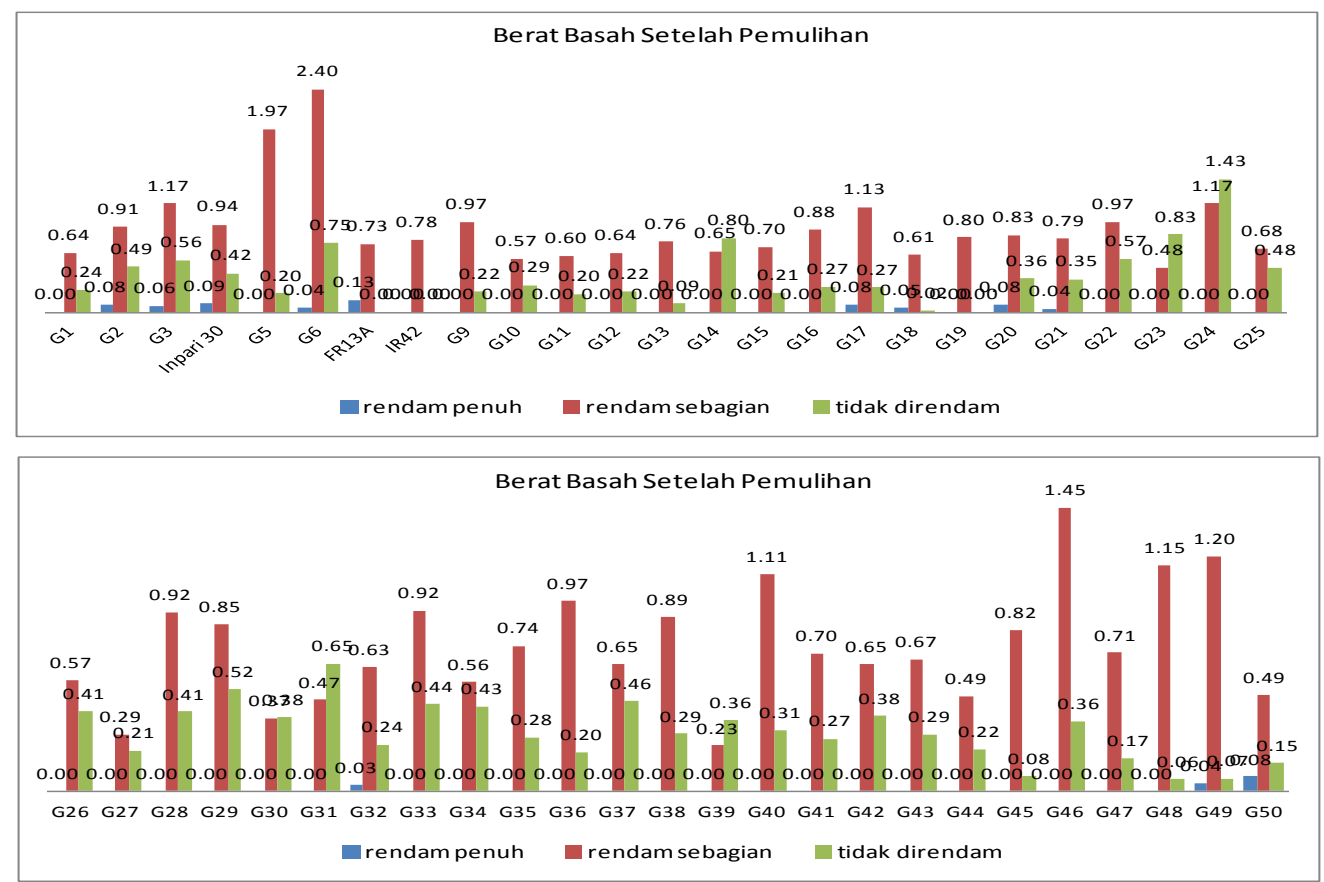

Gambar 7. Berat basah per tanaman (g) setelah periode pemulihan beberapa genotip padi lokal pada tiga perlakuan cekaman terendam

\section{Berat kering per tanaman (g)}

Berat kering tanaman setelah periode cekaman rendaman lebih dipengaruhi oleh varietas padi. Berat kering tanaman yang mengalami rendaman sebagian relative lebih tinggi dibandingkan dengan berat kering 
tanaman yang tidak direndam dan yang terendam penuh. Hal ini disebabkan karena tanaman yang terendam sebagian lebih banyak membentuk karbohidrat untuk mempertahankan dirinya dalam kondisi terendam.

Pada kondisi lingkungan yang terendam penuh, genotipe padi yang sangat toleran yaitu FR13A memiliki berat kering yang lebih besar. Hal ini disebabkan varietas yang toleran terhadap rendaman mampu mengurangi penggunaan karbohidrat selama cekaman rendaman. Menurut Vreinzen et al. (2003), tanaman yang memiliki karakter pemanjangan yang moderat dapat mengurangi penggunaan karbohidrat pada saat terendam.
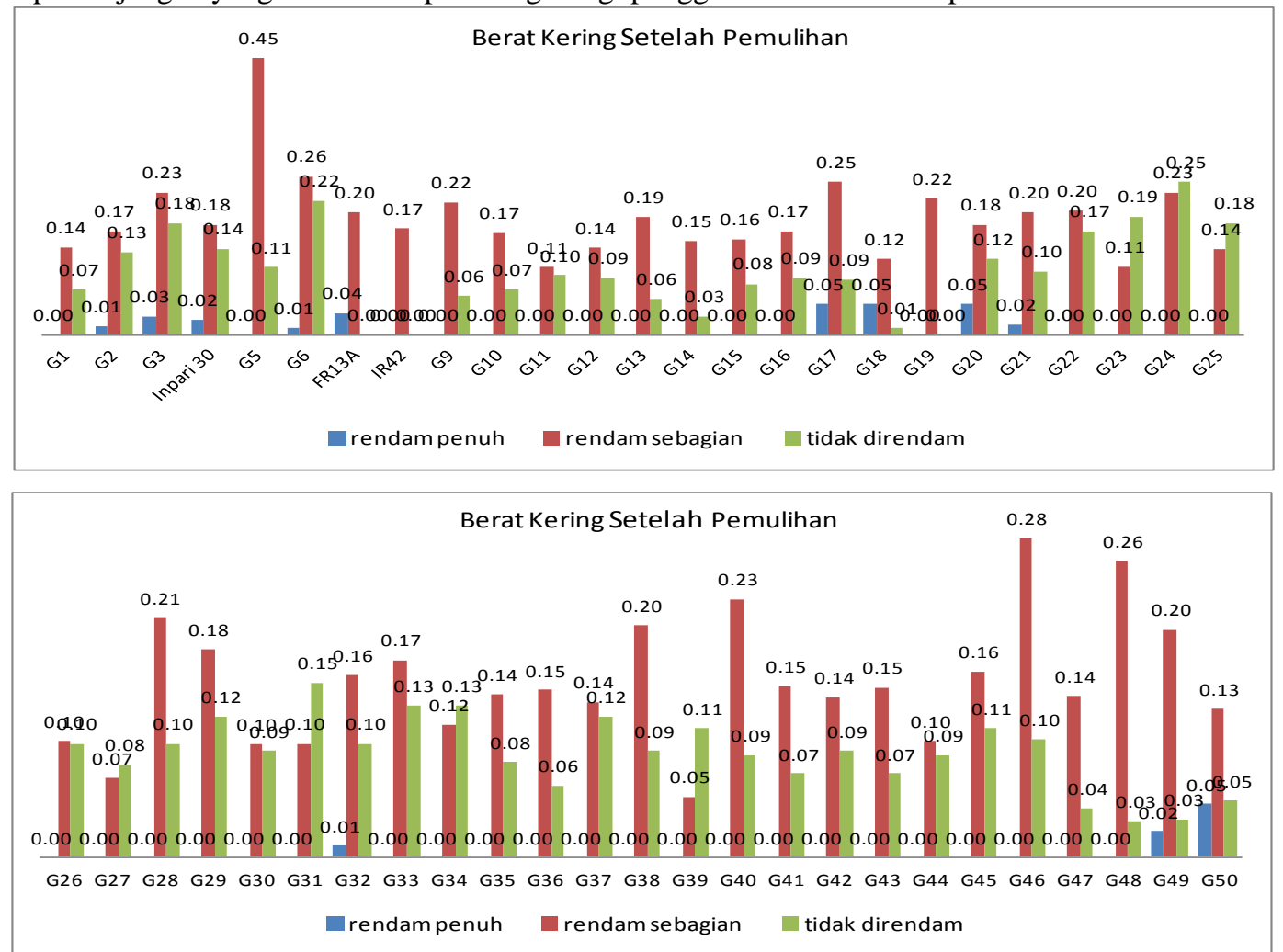

Gambar 8. Berat kering per tanaman (g) setelah periode pemulihan beberapa genotip padi lokal pada tiga perlakuan cekaman terendam

\section{KESIMPULAN}

Semua genotipe padi lokal yang diuji sangat rentan terhadap rendaman, varietas unggul baru Inpari 4 termasuk kategori rentan sedangkan Inpari 30 dan FR13A termasuk sangat toleran.

\section{DAFTAR PUSTAKA}

BB Padi, 2013. Deskripsi Varietas Unggul Baru Padi. Kementerian Pertanian.

CGIAR (Consultative Group on International Agriculture Research). 2006. Intensified Research Effort Yields Climate-Resilient Agriculture to Blunt Impact of Global Warming, Prevent Widespread Hunger Heattolerant Wheat, Flood-proof Rice, Satellites for Carbon Trading Among New Technologies. Press release.ppn4.

Ella, E.S., N. Kawano, Y. Yamauchi, K. Tanaka and A.M. Ismail. 2003. Blocking ethylene perception enhances flooding tolerance in rice seedlings. Funct. Plant Biol. 30:813-819.

Fukao T, Bailey SJ. 2008. Submergence tolerance conferred by Sub1A is mediated by SLR1 and SLRL1 restriction of gibberellins responses in rice. PNAS. 105: 16814-19.

Gomez KA, Gomez AA. 1995. Prosedur Statistik untuk Penelitian Pertanian. Edisi Kedua. (Diterjemahkan oleh Endang Sjamsuddin dan Yustika S Baharsjah). Jakarta. Universitas Indonesia Press.

Harada, T., S. Satoh, T. Yoshioka, K. Ishizawa. 2005. Expression of sucrose synthase genes involved in enhanced elongation of pondweed (Potamogeton distinctus) turions under anoxia. Ann. Bot. 96:683- 692.

Ito, O., E. Ella and N. Kawano. 1999. Physiological basis of submergence tolerance in rainfed lowland rice ecosystem. Field Crops Res. 64:75-90. 
Jackson, M. B., I. Waters, T. Setter, H. Greenway.1987. Injury to rice plants caused by complete submergence: a contribution by ethylerie (ethylene). J. Exp. Bot. 38: 1826-1838.

Nugraha, Y., G.V. Vergara, D.J. Mackil, A.B. Ismail. 2011. Status karbohidrat pada batang bibit padi pada kondisi rendaman keseluruhan dan parsial. hal. 753- 764. Dalam S. Abdulrachman, A. Gani, Z. Susanti (Eds.). Prosiding Seminar Ilmiah Hasil Penelitian Padi Nasional. Sukamandi 24 November 2010.

Nugroho K, Kusuma A, Paidi, Wahdini W, Suhardjo. 1993. Peta areal untuk pengembangan pertanian lahan pasang surut dan pantai. Proyek penelitian Sumber Daya Lahan. Pusat Penelitian Tanah dan Agroklimat. Badan Litbang Pertanian.

Ookawara, R., S. Satoh, T. Yoshioka, K. Ishizawa. 2005. Expression of-expansin and xyloglucan endotransglucosylase/hydrolase genes associated with shoot elongation enhanced by anoxia, ethylene and carbon dioxide in arrowhead (Sagittaria pygmaea Miq.) tubers. Ann. Bot. 96:693-702.

Ray, P.K., D. HilleRisLambers and N.M. Tepora. 1993. Combination of stem elongation ability with submergence tolerance in rice. Euphytica 68:11-16.

Ray, P.K., D. HilleRisLambers and N.M. Tepora. 1994. Genetics of stem elongation ability in rice. Euphytica 74:137-141.

Septiningsih E.M, Pamplona A.M, Sanchez D.L Neeraja C.N, Vergara G.V, Heuer S, Ismail A.M and Mackill D.J. 2008. Development of submergence tolerant rice cultivars: The Subl locus and beyond. Ann Bot: doi:10.1093/aob/men206.

Septiningsih EM, Pamplona AM, Sanchez D L, CN. Neeraja†,Vergara GV, Heuer S, Ismail AM and Mackill DJ. 2009. Development of submergence tolerant rice cultivars : The sub1 locus and beyond. Annals of Botany 103: 151-160.

Setter, T.L., M.B. Jackson, I. Waters, I. Wallace and H. Greenway. 1987. Floodwater carbon dioxide dan ethylene concentrations as factors in chlorosis development and reduced growth of completely submerged rice. In: Proceedings of the 1987 International Deepwater Rice Workshop. International Rice Research Institute, Los Banos, Philippines, pp.301-310.

Xu, K., X. Xu, T. Fukao, P. Canlas, R. Maghirang-Rodriguez, S. Heuer, A.M. Ismai, J. Bailey-Serres, P.C. Ronald, D.J. Mackill. 2006. Sub1A is an ethylene-responsefactor-like gene that confers submergence tolerance to rice. Nature 442:705-708.

Yoshida, S. 1981. Fundamentals of Rice Crop Science. IRRI, Los Banos, Philipines.

Yullianida, Suwarno, S.W.Ardie, dan H. Aswidinnoor. 2014. Uji Cepat Toleransi Tanaman Padi terhadap Cekaman Rendaman pada Vegetatif. J. Agron. Indonesia 42 (2) : 89 -95. 